\title{
Skepticism surrounds diabetes xenograft experiment
}

The news that a team of researchers has 'cured' a patient with Type 1 diabetes using pig islet cells transplanted within a prototype device has roused the diabetes, transplant and xenotransplantation communities. While all are united in the hope that the results are bona fide, the lack of hard data from the study is generating intense skepticism. And the fact that the trial was carried out in Mexico, outside internationally recognized regulatory conditions, is also causing concern. At best, the scientific community has expressed a guarded reaction to the potentially groundbreaking work.

David White of the Robarts Research Institute, University of Western Ontario, and Rafael Valdes of the Children's Hospital in Mexico City, presented details of the study at the XIXth International Congress of the Transplantation Society in Miami in August. Speaking at a press conference, Valdes announced that one of 12 adolescents in the trial has been insulinfree for over 12 months, and 5 others have reduced their insulin requirement. The remainder have experienced no change in insulin use.

James Shapiro, Director of the Clinical Islet Transplant Program at the University of Alberta, who pioneered the successful Edmonton Protocolwhereby donor human islet cells are transplanted into the liversays of the work, "There are a lot of firsts. It's a leap of faith."

Valdes' technique involves the implantation of a cylindrical steel tube, containing an inner teflon bung,

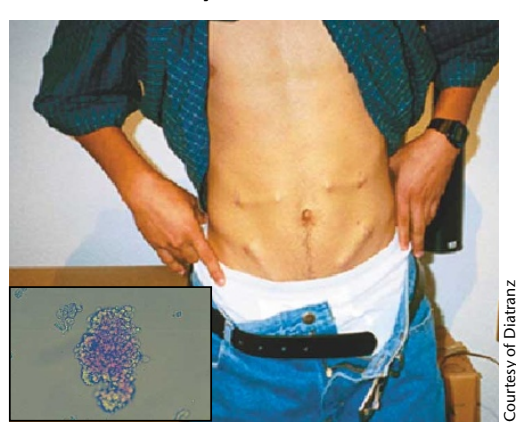

Can a sertoli/islet cell mixture (inset) cure diabetes? because the procedure has not been ratified in non-human primates, or other large animal models. "The experimental data showing efficacy of sertoli cells in preventing autoimmune rejection is not strong. It works in small animal models but has been very hard to replicate in large animal models," says one researcher.

The detail that most engages the skeptics is the production, or lack thereof, of porcine $\mathrm{C}$ peptide. When a molecule of pig insulin is produced, a molecule of porcine $\mathrm{C}$ peptide is also made. Thus, if a cell graft is functioning, circulating pig $\mathrm{C}$ peptide should be detectable in the bloodstream of patients, and should rise after ingestion of food.

The abstract presented in Miami by White states that five patients had "functioning grafts as defined by...production of porcine $\mathrm{C}$ peptide in response to intravenous glucose." However, the team is known to have found extremely low, where detectable, levels of the peptide in patient plasma. Moreover, an independent group lead by Gordon Weir at the Joslin Diabetes Center, Boston, has also failed to find a strong peptide signal in samples. "The measurements we've made thus far are inconclusive," Weir told Nature Medicine, adding, "I think it's a bold set of experiments and we all hope that something like this will work. We're looking forward to resolving the lingering questions about what is happening with these patients, and I'm very supportive of the work."

Sir Roy Calne, who in a subcutaneous pocket in the area of the abdomen. Two months later, once the implant has become embedded in a growth of collagen, the teflon insert is removed and porcine islet cells (pancreatic cells that produce insulin) and sertoli cells (cells that provide immune protection for germ cells developing in the testis) are injected into the tube. The cells were derived from newborn, special pathogen-free pigs, produced by the New Zealand company, Diatranz. Islets are mixed in a ratio of 1:35-50 sertoli cells. Patients are not treated with immunosuppressant drugs.

The trial has generated concern largely pression of exogenous insulin needs without immunosuppression."

If the transplanted islet cells are not functioning, how then are patients able to reduce their external insulin dependency? According to experts, alternative possibilities exist. For example, the patients may have been at an early, incomplete stage of Type 1 diabetes, since patients sometimes present with severe hyperglycemia that goes into remission. This 'honeymoon' period could last for several months.

But many members of the community remain adamant that porcine $\mathrm{C}$ peptide is the definitive test of a functioning islet xenotransplant. Hugh Auchincloss, Professor of Surgery at Harvard Medical School, told Nature Medicine, "This group has been repeatedly asked to provide porcine $\mathrm{C}$ peptide and histologic data to support their claim that they have achieved meaningful survival and function of pig islets. Not having seen these data, I do not believe that this group has accomplished successful xenotransplantation."

Another point of controversy is the use of sertoli cells to protect the transplanted islet cells and the concomitant lack of treatment with anti-rejection drugs. As Shapiro explains, "Sertoli cells produce a thousand different products in the testes to prevent auto-reactivity of sperm. When they are transplanted together with islets, the concept is that they secrete Fas ligand and other inhibitory molecules [to prevent destruction]. But it's not been tried before in people." In fact, sertoli cell protection of islet transplants has not proved effective in large animal models to-date.

Similarly, the delivery cylinder used by Valdes has not been described in preclinical models. And there are reservations about its subcutaneous placement. "All previous attempts to use a subcutaneous site to transplant islets have failed miserably in animal models," says one investigator. "This is because of the poor dynamics of glucose and insulin absorption in the surrounding milieu of an s.c. site."

Ethically, such an experiment cannot be balanced by control data. For example, it is not possible to remove the device and show that diabetes returns. For this reason the community is pressuring the group to test the approach in non-human primates, dog or rabbit. Valdes has agreed, but has also begun trials in a further 24 patients.

Karen Birmingham, London 